\title{
Transport Technology in the Function of Water Transport Development in the Republic of Croatia
}

\author{
Grgo LUBURIĆ, Damir BUDIMIR*, Ivan BORTAS
}

\begin{abstract}
The Republic of Croatia, which has geo-traffic predispositions for the development of river traffic as one of the least expensive transport modes, with the lowest percentage of environmental pollution, should tend towards strategic and planned objective of being implemented into the Trans-European Transport Network by the construction of the Danube-Sava river canal, channelling of the Sava river for smooth navigation in the navigability class of Vb category, expansion and modernisation of the existing port capacities along the waterways and the expansion of the Sava waterway to Zagreb. The subject of the research is based on the assumption that will zoom in the navigability class to achieve a balanced use of the natural resources and a reduced energy use and environment pollution, which would reduce the cost of transportation, emissions and risks of accidents, especially in the transport of dangerous goods.
\end{abstract}

Keywords: Croatia; energy consumption; environmental pollution; Trans-European Transport Network (TENtec); waterways

\section{INTRODUCTION}

Monitoring and determining the transport process and the technical and technological characteristics have been based on the laws of qualitative and quantitative indicators, concretely measurable with the aim of improving and enhancing the transport service. The significance of studying the technological laws of the transport of goods and services in time and space aims at optimisation, reduction of duration and improvement of the technological flow of the traffic process. The efficiency and safety, technical equipment level and professional qualification of the staff in the control and supervision are the basic criteria and starting aspects of evaluating and improving the quality of the transport technological process. The capability of timely location and identification of the process problem to convert the time criterion into a spatial one, are the laws which are studied by the discipline of technological system and process in traffic. By planned and controlled redistribution of cargo flows from road transport mode to inland navigation, it is possible to reduce the energy consumption and environmental pollution and reduce the transportation costs. For this purpose, the impact of upgrading the navigability class, construction of the Danube-Sava Canal, reconstruction and modernisation of inland waterways. The results should prove to redistribute cargo flows from road transport modes to inland waterways and increase the buoyancy class, increase the capacity of river cargo flows, which would lead to a reduction in energy consumption and environmental pollution, and thus to a reduction of external costs caused by traffic accidents. Its construction becomes important in the context of searching for alternative routes of goods transport between the north and the south of Europe and alternative transit routes for overseas freight. At the micro level, it is important for connecting to the transport corridors of the European Union and the Danube region. Its realisation would create the preconditions for a better redistribution of transport in favour of river transport, which is one of the objectives of the NAIADES II - Towards quality inland waterway transport.

One of the most significant directives published in the White Paper refers to the increase of the share of other forms of traffic as alternatives to road traffic, particularly in freight transport. This paper analyses the effect of the navigable Danube-Sava canal, as a segment of the infrastructure of multimodal and/or intermodal transport, and analyses the information from transport management on the transport resources in particular segments, which enables planning and proactive forming, improvement of transport services on the basis of valorisation of economic, safety and ecological parameters [1]. The preliminary design of the transport infrastructure in the territory of Croatia which presumes the construction of the DanubeSava canal was realized on the basis of similar examples from the world, and by the method of analysing what would happen if there was a navigable canal as a segment of multimodal transport infrastructure. The main goal of this paper is to develop the solution that would eliminate the obstacles preventing the development of multimodal transport, while taking in consideration the interconnections between the traffic subsystem of river corridors and the company traffic subsystem. For example, the paper [2] presents the method that enables the elimination of the existing obstacles in combined transport by the concept of a multi-agent system. The paper presents different researches of the possibilities of implementation of multimodal transport into logistic processes on the traffic network in Poland.

To alleviate the consequences of the increase of traffic congestion connected with ever growing demands for transport of people and goods, it is justified to invest in strategic infrastructural facilities and, concurrently, into transport service providers arisen from them, with the goal of reducing the costs and the time of transport and improving safety and ecological parameters (emission of $\mathrm{CO}_{2}$ ) that are by-products of transport processes [3].

The importance of inland waterways in the Republic of Croatia with regard to the location of international corridors, especially for the transportation of cargo in geospatial distribution, is important for strategic negotiation and defining the Adriatic Ionian corridor, which is important for Croatia. In addition, with the support of the Vc corridor, the $\mathrm{X}$ corridor could be rehabilitated too, which would allow Croatia to be better integrated into the TEN-T network, especially the railways, which are often supplemented from the technological point of view. Therefore, in order to increase the Croatia's transport capacity for goods transport, a free and non- 
discriminatory access to inland waterways is of primary importance, given the fact that the function of transport is carried out by a larger number of operators on the intermodal national transport network.

\section{TECHNOLOGICAL ASPECT OF TRANSPORT}

According to technological and organisational characteristics the traffic is classified into regular, line and free, i.e. transport o. The commercial characteristics of river transport usually include the massive scale of transport, transport speed, preservation of goods and transport safety. The research of the competitiveness of internal waterways on the example of Myanmar (Burma) confirmed the justification of investing, as well as of investments connected with the challenges of the implementation of this form of transport in the overall traffic system. Among different transportation modes, inland water transport is recognized as a low-cost, ecologically acceptable way of transport [4]. The recommendations for improvement of the transport efficiency in the sense of time, price and reliability from the company viewpoint were also considered and given, and, based on that, the potential and aspects of integration of models were identified.

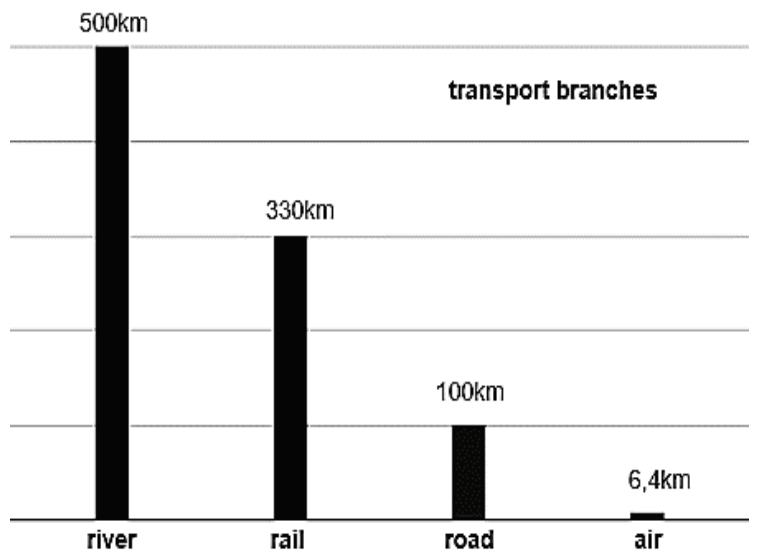

Figure 1 Transport range per traffic branches per ton with constant energy quantity; Source: Mid-term development plan of waterways and ports of inland waterways of the Republic of Croatia (for the period 2009-2016), Ministry of the Sea, Transport and Infrastructure, 2008 [6]

The highest share in the total transport is accounted for by ores, raw non-metal minerals, oil and derivatives as well as cereal crops. In order to avoid unnecessary delays and waiting in the transport cycle flow and to achieve maximal commercial transport velocities, the implementation of the plan of Harmonising fleet and port capacities is of special significance. The Organisation for Inland Transport of the European Economic Commission of the United Nations in Geneva has classified the European rivers regarding the size of ships that can navigate along them [5]. For waterways of inter-state significance when introducing the connecting rivers or constructing artificial canals to connect the neighbouring countries class IV has been adopted, i.e. class for ships of up to $1500 \mathrm{t}$ capacity. It has been found that the transport along rivers is up to five times more cost-efficient compared to road, rail or air transport. With the same unit energy consumption in inland water transport one can travel a five times longer transport path per ton-kilometre compared to road transport, or three times longer relation than can be realised in railway traffic (Fig. 1).
By this, the opinion is expressed that, in certain circumstances, transport services can be shaped and improved through new infrastructural transport resources, which need to be planned in time so as to avoid a demanding and expensive transformation of the transport service providers and avoid introducing of restrictions.

\section{CURRENT SITUATION OF WATER TRANSPORT IN EUROPE}

The European network of inland waterways consists of more than 30000 kilometres of rivers and canals interconnected. The main transport network consists of four navigation corridors, that are part of the TEN-T network of the European transport routes, and they are: Rhine-Corridor, North-South Corridor (which includes the rivers and canals of the Netherlands, Belgium and France), Eastern Corridor (consisting of rivers and canals from Germany to Poland and the Czech Republic) and the South-eastern Corridor-Danube (including Main, Danube and the Main-Danube Canal as well as the flow of the Danube River to the Black Sea), which realised almost $96 \%$ of the overall inland water transport of Europe. The river transport of Europe has, unlike road transport (74\%) and rail transport (14\%) very low percentage share in the overall surface freight transport of as little as $7 \%$ with carried freight of 650 million tons annually or about 125000 million ton-kilometres. In the countries of Benelux and the northern France the share of river transport in freight transport is much higher and reaches up to $43 \%$ of the total realised freight transport. The Rhine River is the main route, of the total length of $1320 \mathrm{~km}$, navigable from Basel and allowing navigation of ships with draught of up to $3,5 \mathrm{~m}$ from Rotterdam to Cologne, covering a stretch of about $250 \mathrm{~km} \mathrm{[7].} \mathrm{The} \mathrm{efficiency} \mathrm{of} \mathrm{investing} \mathrm{into} \mathrm{the}$ corridors for freight transport in Europe is treated in the paper [8]. The concept is harmonised with the European Commission's goals for improving the modalities of multimodal transport under the motto: from the road to inland waterways

\section{CURRENT SITUATION OF WATER TRANSPORT IN CROATIA}

The Republic of Croatia has started the harmonisation of the transport system and the development of the transport infrastructure with the state priority requirements $[9,10]$. Comprehensive projects regarding development of roads, coast fleet, civil aviation and ports and other projects are being successfully realised. The most important Croatian transport routes have become part of the PanEuropean network of the main transport corridors, thus confirming the significance of the transport location of Croatia [11]. In the five-year period, in the inner water turnovers, the Croatian ones achieved the maximum traffic results in September 2010, of 7,4 million tonne-kilometres, and since then, the same have been in a constant decline (Fig. 2).

Achieved transport on inland waterway transport (domestic and international traffic) in 2013 amounted to 5,82 million tons (of which 5,25 million tons in transit on the Danube, and 577 thousand tons annually) or approximately $0,58 \%$ of the total transport of goods in the Republic Croatia (Fig. 3). 


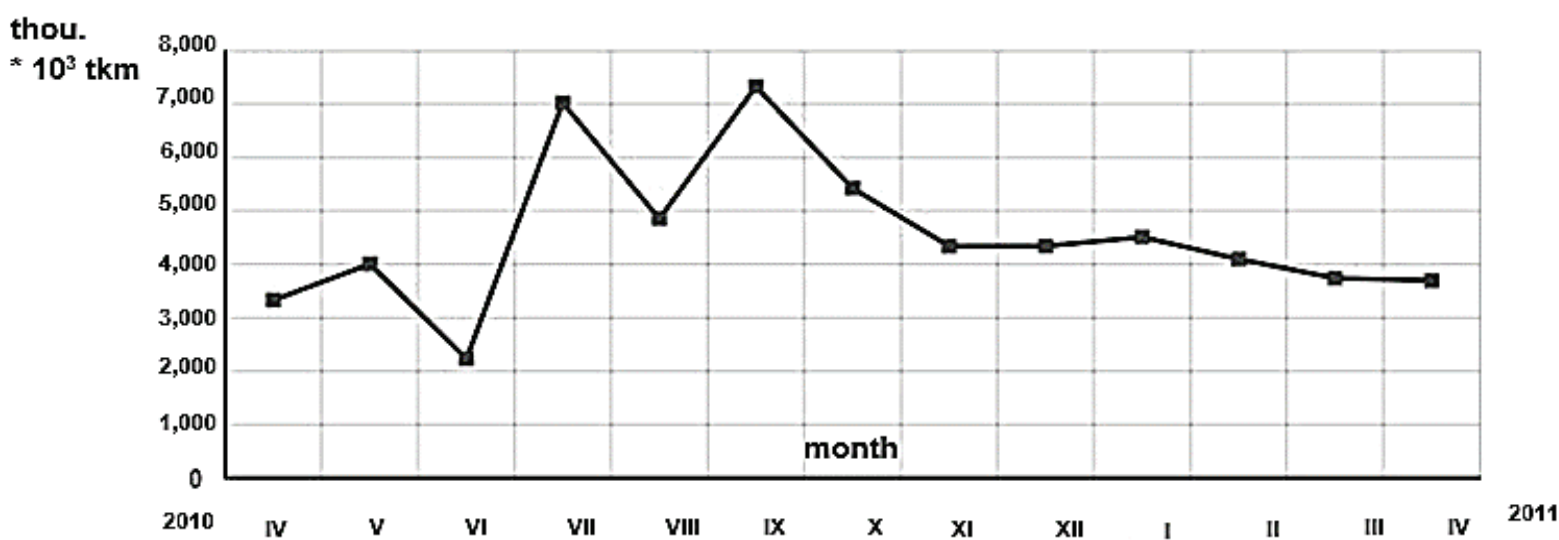

Figure 2 Realised transport ton-kilometres on inland water transport for 2010 and first six months of 2011 Source, in $10^{3}$ of carried tons; Source: Croatian Bureau of Statistics [12]

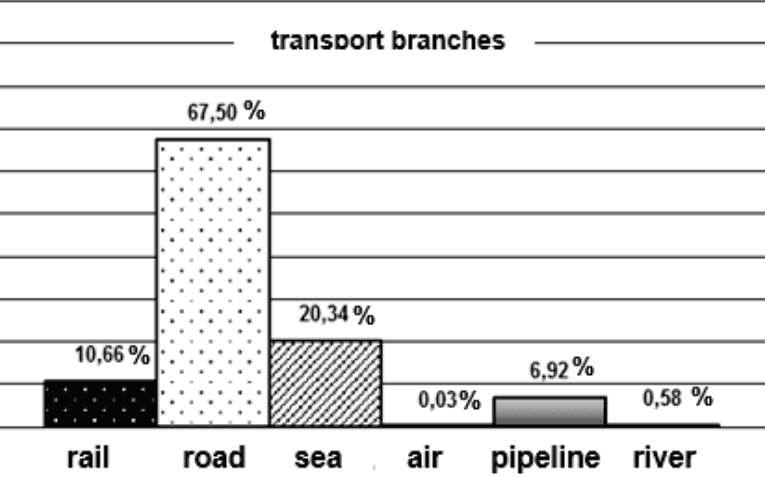

Figure 3 Expected mass structure of freight transport per traffic branches in the Republic of Croatia [12]

The total length of the waterways in Croatia amounts to $805,20 \mathrm{~km}$. The total length of the waterways in the Sisak-Moslavina County amounts to $117 \mathrm{~km}$ on the Sava
River and $5 \mathrm{~km}$ on the Kupa River (Tab. 1). The navigability of the Sava River for merchant vessels is from the mouth Vel. Struga to the mouth of the River Kupa, and with permission the part also upstream up to the ship slip at the bridge in Galdovo is used. The River Kupa is navigable from the mouth in the Sava River to the mouth of the Odra into the Kupa. A section of the Sava River upstream from Galdovo and the Kupa River upstream from the mouth of the River Odra is used exclusively for transport which serves for gravel exploitation and the maintenance of ferryboats connecting the settlements on the opposite riverbanks.

The revival of river transport with further development of the river ports, in the sense of attracting business and using the advantages of the more favourable and environmentally friendlier transport mode, should be set as the priority development objective of transport strategy.

Table 1 Classification of waterways in Croatia

\begin{tabular}{|c|c|c|c|}
\hline River & River section - chainage & Length of waterway $/ \mathrm{km}$ & Waterway class \\
\hline DANUBE & Ilok - Batina & 137,50 & Class VIc \\
\hline \multirow{5}{*}{ SAVA } & Račinovci - Sl. Šamac & 102,90 & Class IV \\
\hline & Sl. Šamac - 330+200 Oprisavci & 24,50 & Class III \\
\hline & Oprisavci - Sl. Brod-town & 33,00 & Class IV \\
\hline & Sl. Brod-town- Sisak & 219,80 & Class III \\
\hline & SisakRugvica & 68,00 & Class II \\
\hline \multirow{3}{*}{ DRAVA } & Mouth of Danube - Osijek port Nemetin & 14,00 & Class IV \\
\hline & Osijek port Nemetin-Belišće & 41,40 & Class III \\
\hline & Belišće $-198+600$ & 143,20 & Class II \\
\hline KUPA & $0+000-5+900$ & 5,90 & Class I \\
\hline \multirow{2}{*}{ UNA } & $0+000-4+000$ & 4,00 & Class II \\
\hline & $4+000-15+000$ & 11,00 & Class I \\
\hline & TOTAL LENGTH OF CURRENT WATERWAYS: & & \\
\hline
\end{tabular}

Source: Mid-term development plan of waterways and inland waterway ports of the Republic of Croatia (2009-2016), Ministry of the Sea, Transport and Infrastructure, 2008 [6]

The study has found that the construction of the new Danube-Sava Canal, the reconstruction of the current waterways (by upgrading the navigability class of the River Sava), modernisation of the ports and introduction of new technologies, the navigability share in the Republic of Croatia would be increased from the current $287,40 \mathrm{~km}$ to $531,70 \mathrm{~km}$ or from $35,6 \%$, (Tab. 1) to $66,10 \%$, (Tab. 2).

The current capacities and the structure of transport, shown in Tab. 1 and Fig. 2 and 3, could be increased as shown in Tab. 2 and Fig. 4.
The European Commission published a White Paper in 2011 [3], entitled "Roadmap to a Single European Transport Area - Towards a competitive and resource efficient transport system", in which 60 measures were proposed for restructuring the EU transport policy to create a more sustainable system with less pollution and congestion. Some of the measures are aimed at reducing $\mathrm{CO}_{2}$ emissions by $20 \%$ and the replacement of at least 10 percent of the amount of fossil fuels and biological fuels by 2020 to reduce the total domestic consumption by $20 \%$ [3]. 
Table 2 Classification of waterways in Croatia following navigability class upgrading

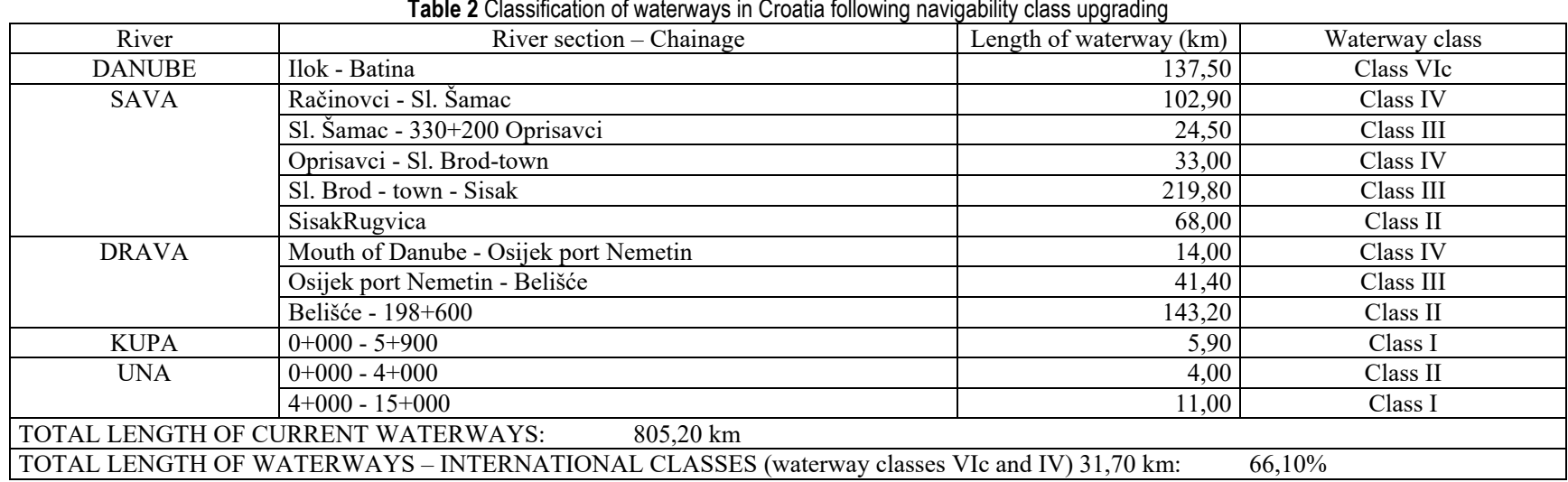

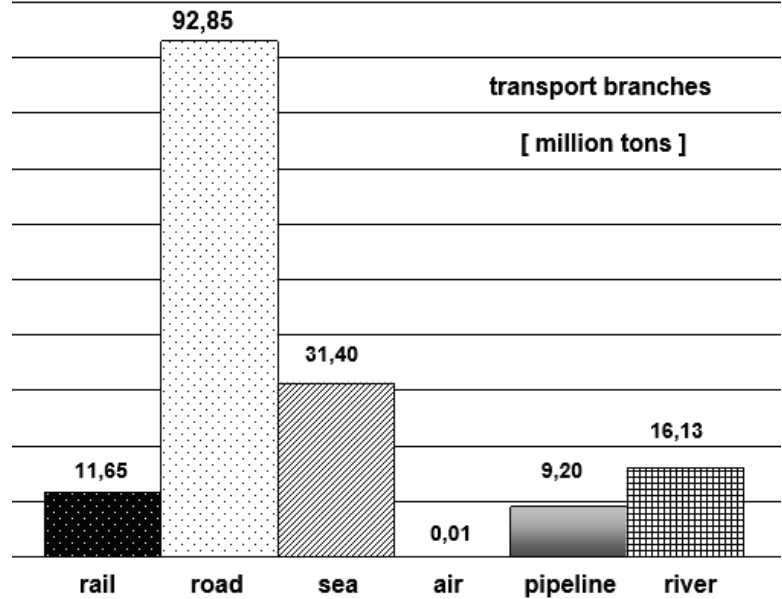

Figure 4 Expected mass structure of freight transport per traffic branches in the Republic of Croatia

The transport sector is one of the most intensive consumers of energy. In Croatia, in the period from 1991 to 2013 , the share of energy consumption of the transport sector in final consumption increased from $21 \%$ to $35,1 \%$ (Source: Energy Institute Hrvoje Požar (EIHP), 2013). Energy consumption in Croatia by type of traffic in the Republic of Croatia in the period 2007-2013 (Tab. 3). External costs (The external costs caused by road accidents, air pollution, noise and climate change belong to the category of costs significantly burdening the GDP of a country) for internal water transport are significantly lower than for the railway, and several times lower than for road transport.

The reorganization of cargo flows from the road transport mode to the internal waterways path to significant savings in energy consumption, environmental pollution and reduction of external costs because it has been established that the inland waterway has $20 \%$ lower costs compared to road, rail or air transport and is a smaller polluter. With a constant amount of energy, inland waterway transport can achieve up to five times the length of transport compared to road transport.

Table 3 Traffic in the Republic of Croatia (PJ)

\begin{tabular}{|c|c|c|c|c|c|c|c|}
\hline & 2007 & 2008 & 2009 & 2010 & 2011 & 2012 & 2013 \\
\hline Rail transport & 2,07 & 2,06 & 1,84 & 1,84 & 1,76 & 1,66 & 1,54 \\
\hline Road transport & 81,49 & 79,97 & 80,03 & 77,13 & 76,69 & 74,30 & 75,17 \\
\hline Air transport & 4,50 & 6,07 & 4,38 & 4,66 & 4,92 & 5,07 & 5,55 \\
\hline Maritime and inland waterway transport & 1,56 & 1,88 & 2,07 & 1,66 & 1,66 & 1,68 & 1,71 \\
\hline Public city transport & 1,36 & 1,40 & 1,43 & 1,46 & 1,41 & 1,36 & 1,36 \\
\hline Others transports & 0,10 & 0,09 & 0,09 & 0,08 & 0,07 & 0,07 & 0,09 \\
\hline Total transport & 91,07 & 90,47 & 89,84 & 86,80 & 86,39 & 84,02 & 85,41 \\
\hline
\end{tabular}

Source: Energy Institute Hrvoje Požar, Zagreb, 2013.

\section{PERSPECTIVE OF TECHNOLOGICAL DEVELOPMENT OF WATER TRANSPORT IN THE REPUBLIC OF CROATIA}

\subsection{Construction of Danube-Sava River Canal and} Reconstruction of River Infrastructure Network

The construction of the planned "Danube-Sava" Canal from Vukovar to Šamac would be the main connection of Croatia with the inland waterways of Europe. The canal would shorten the waterway between the Danube and the Sava by $417 \mathrm{~km}$, between Šamac and Belgrade by $85 \mathrm{~km}$ and it would improve the speed and quality of navigation. As part of the Danube Corridor VII the Canal would enable integration of the Croatian waterways and connection of the Trans-European inland waterway Rhine-Main-Danube with the sea, i.e. the Croatian seaports Rijeka and Ploče. The Canal is conceived as a connection between Central Europe and the Adriatic Sea, with the aim of competitive attraction of freight transport from other transport modes and flows. The connection of the Croatian network of inland waterways within Croatia would realise annual turnover of 16,13 million tons of freight with the assumed annual growth rate of $2,5 \%$ and possible achievement of the planned capacity of 20 million tons annually until 2020 $[13,14]$.

According to the mentioned data and by a comparative analysis of the effects and requests for changes and/or improvements of the services and processes, it can be ascertained that a large part of the indicators referring to transport of people and goods is determined positively. Fig. 5 shows direct and indirect impacts and effects of the construction of the Danube-Sava canal on the micro location.

Studies based on researching waterways in populated areas have shown the environmental benefits of their use in multimodal transport. For example, the scientific paper 
entitled [15] shows the importance of making decisions directed towards greater exploitation and efficiency of waterway transport with the goal of improving harmful effects of transport on air quality in cities located in the area of waterways. European Commission has strategically provided guidelines for stimulating the development of sustainable transport networks for the transport of cargo in the EU. In that sense, the paper [16] firstly discusses the feasibility of establishing waterways, especially for the cargo transport between the east Mediterranean (over the Aegean Sea) and the river Danube. Then it continues with the analysis of energy consumption and influence on air, as well as with the comparison of achieved quality with the other ways of transport, such as rail and road. In the end, it establishes the technical feasibility of transport services by waterways and confirms their energy and environmental efficiency. Therefore, it concludes that waterways represent a good alternative to roads and railroads. The superiority of waterways in relation to land transport is confirmed especially in cargo transport, where the research was conducted regarding certain emission standards applied to various ways of transport.

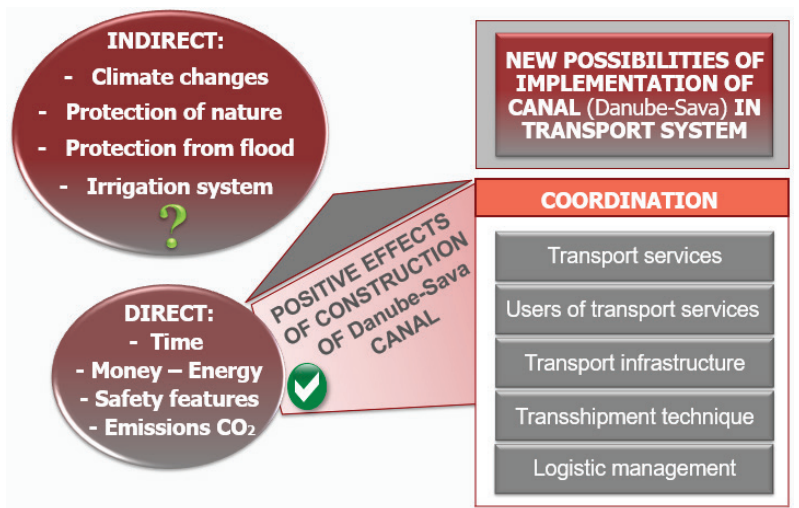

Figure 5 The expected possibilities and parameters that are consequently connected with the construction and use of the Danube-Sava canal

The Danube-Sava waterway model in the southeast Europe would improve the existing way of transport by a greater share of this alternative approach to transport with presented advantages. For the needs of the model, the capacity of the waterways was assumed to be less than the theoretical one, and thus the exploitation transport capacity was calculated. The sequential aggregate model was applied by the so called four-stage travel demand model determined by the capacity of the exploitation transport canal Danube - Sava and the transport demand through that canal. An important characteristic of the applied sequential model is that it is based on the assumption that the function used to describe the transport does not depend on the transport offer (time of transport for certain sections, price, frequency of transport) but it depends exclusively on demand, i.e. socio-economic characteristics of the zone. The influence of transport offer (which is closely connected with the choice of the means of transport) on the choice of transport has not been the subject of this research. The theoretical capacity was provided for ideal conditions, i.e. not related with subjective or objective interferences which may appear during waterway exploitation. It is calculated by reducing the theoretical capacity with an experiential coefficient. It was shown that the exploitation coefficient amounts to $10-20 \%$. The exploitation capacity was measured, i.e. calculated on the basis of the accepted coefficient of $18 \%$ :

$M 1_{\text {expl.direct. single }}=M_{\text {sum.theore }} \cdot 18 \%=6.2 \times 10^{6}$ (tons $/$ year $)$

It is important to emphasize that the (transport) capacity of the canal directly depends on the capacity of the main lines (the Sava and the Danube). Besides the transport of goods, the function of the future transport demand is expressed through a sequence of functions reflecting each of the mentioned starting stages defined in relation of people and goods transport, namely: according to the zones of people transport, transport distribution and division of transport by means of transport.

The first two stages reflect the spatial transport distribution according to the level of construction of the transport infrastructure and they encompass:

1. The length of networks of all (alternative) roads

2. Speed of vehicles on transport network sections

3. Network quality (safety of sections, the capacity of transport ways, etc.)

4. Number, location and size of terminals in zones and the choice of locations for new terminals

5. Critical points in the system (transport management).

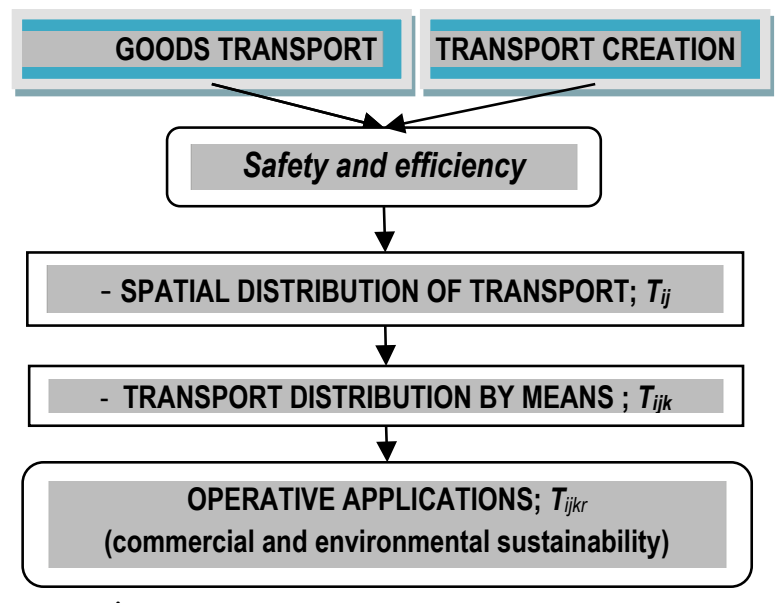

iFigure 6 Category model for data processing through stages

The calculation (Method for Transport Anticipation) uses a series of data for the past period obtained through the processing of data for a certain section of time. In that sense, particular attention was paid to the process of emerging, and especially the process of attracting transport (Fig. 6). Depending on the type of data used and the observed unit (aggregation), the category method of analysis was applied by which the creation of transport was estimated on the basis of transport demand characteristics, processing the data of time average and zone characteristics.

The function of the future transport demand is expressed through a sequence of functions reflecting each of the mentioned stages, whereby $T_{i j k r}$ expresses the size of transport from zone $i$ into zone $j$ with means of transport $k$ on route $r$, which assumes in the model that $T_{i}$ was estimated first, followed by $T_{i j}$, then $T_{i j k}$ and in the end $T_{i j k r}$. Each stage is predetermined by the result of the previous stage, as this is a sequential model and requires the creation of a mathematical model with a certain complexity and degree of reliability. 


\subsection{Development of Modern Transport Technologies and Intermodal Transport}

The geo-traffic location of the Republic of Croatia is extremely favourable and significant for the establishment of efficient connections on inland waterways between Western and Central Europe and the Adriatic Sea and the Mediterranean. Adequate development of the waterway network which would achieve certain standards, would improve the interoperability of the Croatian and the European waterways (Fig. 7).

The development of modern transport technologies means development elements of integral, Intermodal and combined transport. The shifting of transport flows from unimodal road transport towards Intermodal transport, by rail and inland navigation canals, with today's container vessels (river ship class JOWI, load capacity 470 TEU, capacity 235 containers), includes numerous advantages: reduced energy use, more cost-efficient transport price, lower impact on the environment, reduction of the emission of harmful gases, reduction in the number of traffic accidents, where accident risk is much lower on rail and waterways than on the roads, which is especially important for the transport of dangerous freight. The integration of the transport network into a unique transport system of Europe is defined as the basic element of the European Union transport policy.

For the development of Intermodal transport network in the Republic of Croatia, along with the establishment of river navigation, the parallel development of railway infrastructure is also very important, as well as the connecting of the existing road network into a unique transport system [17]. Rail transport development is the primary task, which in the first place means restructuring of the existing railway lines and the construction of a new connecting rail network with the aim of achieving efficient operation on market bases, with gradual decrease of the state subsidies. The increase of traffic in general and as part of it, also the increase in river transport will intensify also the development of river ports, quay, and transport terminals along the entire Danube Basin - Adriatic Corridor, and especially in the region of eastern Slavonia, Zagreb, Sisak, Rijeka, Ploče, Split, Šibenik and Zadar.

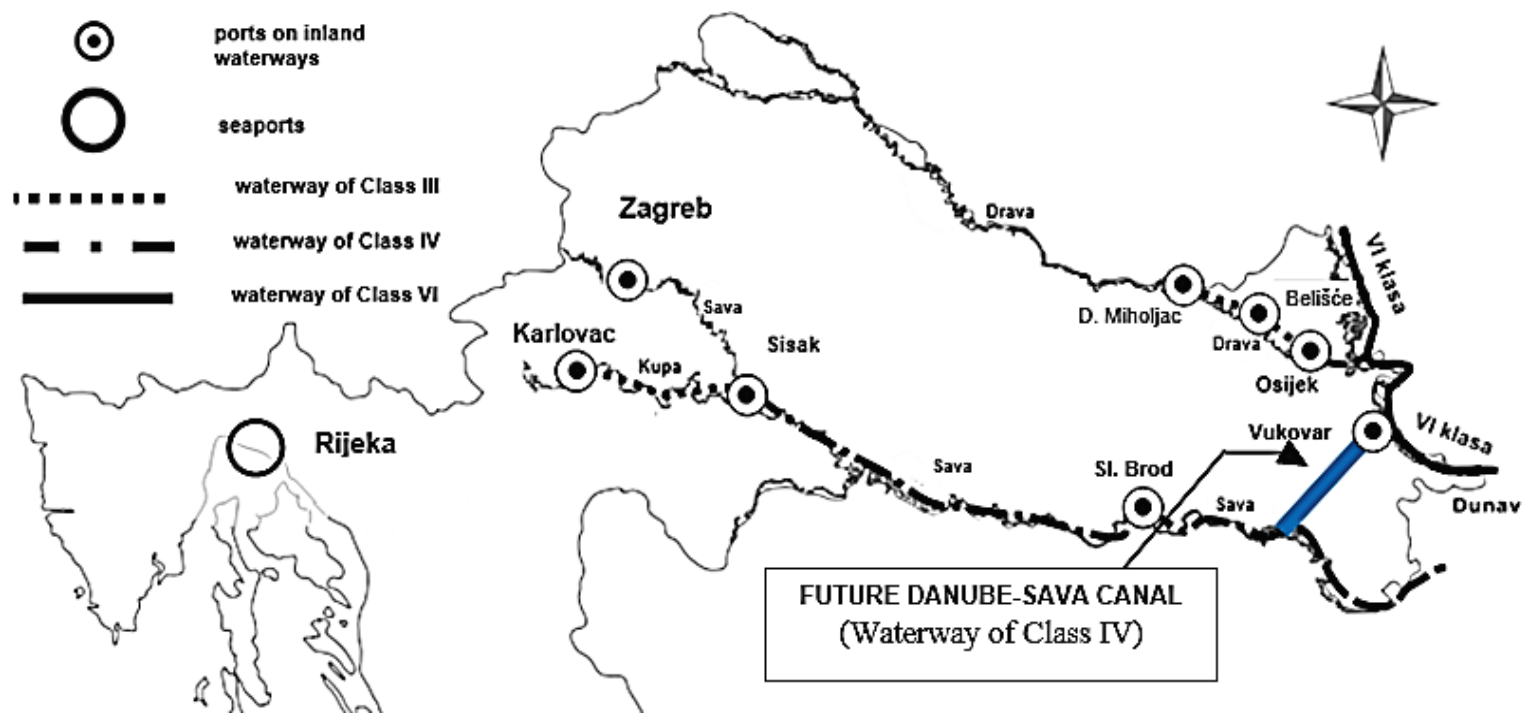

Figure 7 Development of river transport network in the Republic of Croatia; Source: Program of development projects in Croatia; Croatian Chamber of Civil Engineers, March 2010 [11]

\subsection{Development of River Ports and Freight-Transport Terminals}

Along with the development of waterways the current river ports require modernisation. The main aim of every river port, regardless of its size, type and geographical location, is to act as interface between the water and surface transport means - that is, efficient transhipment from ships to land and from land to ship [18]. Following the market development, especially of regional transport market, there may appear and develop additional objectives that under certain circumstances may significantly exceed the primary goal [19]. The planned annual capacity of freight transport is presented in Tab. 4.

The Croatian river ports need high-quality and technological modernisation in order to satisfy the existing and expected demand. Apart from modernisation of the basic port infrastructure, the safety and surveillance system in the port area needs to be strengthened. The ports need to be connected with the main road and rail corridors in order to achieve improved coordination with the economic hinterland and to create preconditions for the development of Intermodal transport.

Table 4 Planned annual capacity of freight transport in intermodal transport until

\begin{tabular}{|c|c|c|}
\multicolumn{1}{c|}{2020} \\
\hline Infrastructure Type & Location & $\begin{array}{c}\text { Annual Capacity } \\
/ \text { mil. tons }\end{array}$ \\
\hline port & Rijeka & 55 \\
\hline port & Vukovar & 10 \\
\hline port & Karlovac & 10 \\
\hline port & Sisak & 10 \\
\hline port & Slavonski Brod & 5 \\
\hline navigable canal & Danube-Sava & 20 \\
\hline rail & Rijeka-Zagreb & 50 \\
\hline rail & Zagreb-Vinkovci & 70 \\
\hline
\end{tabular}

Source: Program of development projects in Croatia; Croatian Chamber of Civil Engineers, March 2010 [5]

The annual turnover represents one of the most important technological parameters that are used to assess the market success of a port or port system (Tab. 5). 
Table 5 Planned annual capacity of freight transport in intermodal transport until 2020

\begin{tabular}{|l|l|c|}
\hline \multicolumn{1}{|c|}{ Infrastructure Type } & \multicolumn{1}{|c|}{ Location } & $\begin{array}{c}\text { Annual Capacity / } \\
\text { mil. tons }\end{array}$ \\
\hline Kupa waterway & Sisak-Karlovac & 10 \\
\hline Sava waterway & Sisak-Slavonski Šamac & 20 \\
\hline port & Karlovac & 10 \\
\hline port & Sisak & 10 \\
\hline port & Slavonski Brod & 5 \\
\hline port & Vukovar & 10 \\
\hline port & Osijek & 5 \\
\hline
\end{tabular}

Source: Program of development projects in the Republic of Croatia Croatian Chamber of Civil Engineers, March 2010 [5]

River ports are important connection points, not only for the physical throughput of goods, but also for extensive information flow through multimodal transport chains. Numerous participants in these transport chains create a number of data exchange interfaces. The rule is for the ports to cooperate with the shipping companies, private ship owners, forwarders, public and private rail companies, truck companies, freight handling companies, local population, public authorities, users and receivers of freight. The basic principles of the port operation are:

- public character of ports and the availability of port capacities to all users,

- liberalisation of port service market,

- equal handling of all the users and no discrimination,

- coverage of port costs by port customers,

- provision of high standards of safety and environmental protection.

The Croatian port system consists of several ports that are located at strategic positions of all the Croatian navigable rivers. The biggest among them is the Port of Vukovar on the right bank of the River Danube, then the Port of Osijek on the right bank of the River Drava, and the Port of SlavonskiBrod on the left bank of the River Sava. The port area of Sisak encompasses two separate port terminals - Port of Crnac on the right bank of the River Sava and the Port of Sisak on the left bank of the River Kupa (Fig. 8).

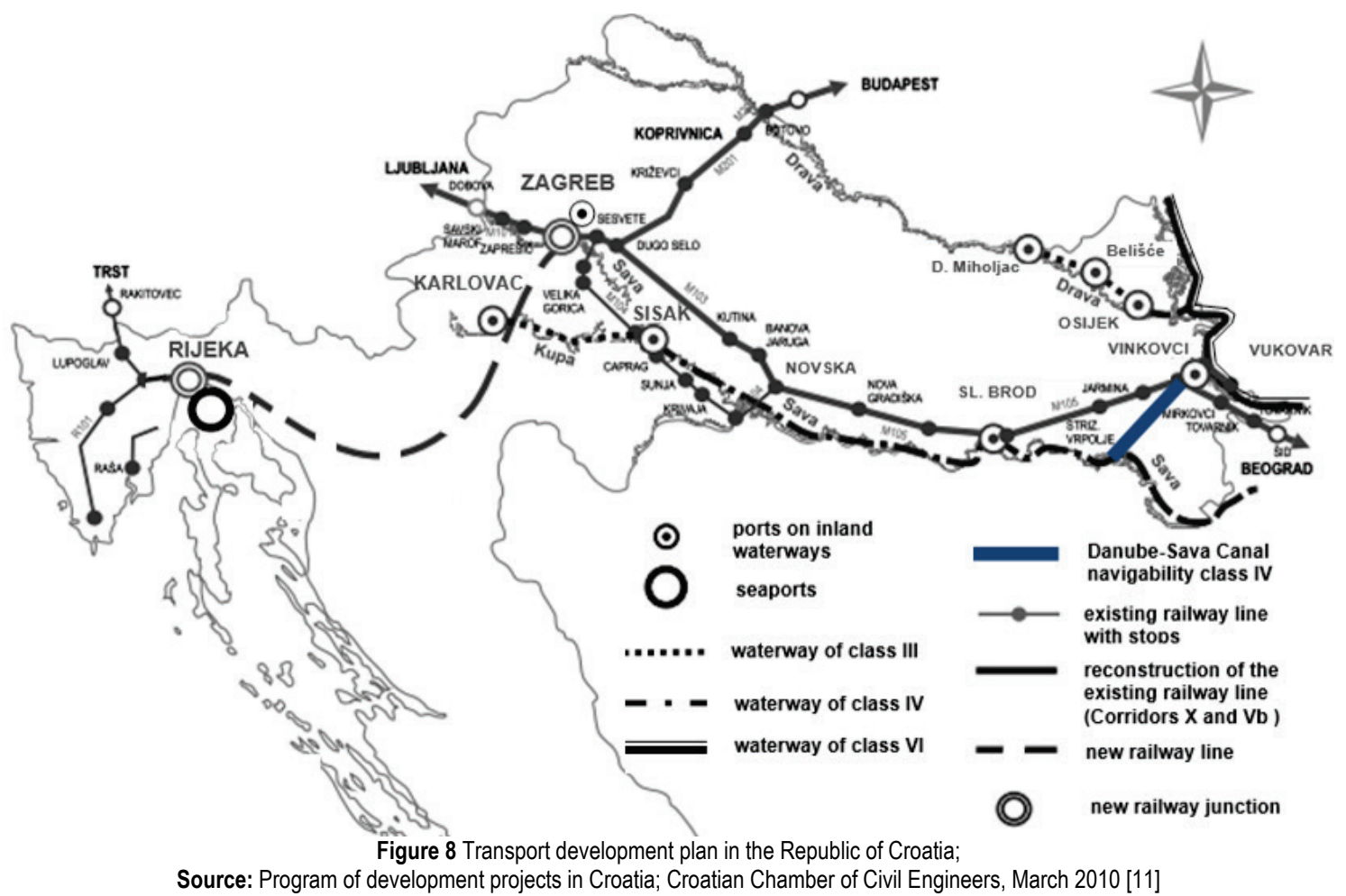

Apart from the river ports, the smooth functioning of Intermodal transport flow requires the construction of distributive goods terminals and logistic centres, as connections of various transport branches. The most important condition for positioning of the goods terminals is the criterion of goods flows, physical and technological characteristics, locations and organisational capability. The planned construction of the distribution goods terminal should be located at the traffic flow nodes, i.e. nodes of traffic corridors of combined traffic, along the central geotraffic and economic centre of Croatia, immediately next to the nodes of the main traffic corridors of the European Union, whose facilities will unite road, rail, air and water transport.

In order to determine the seaports value on a particular geographic area, the research of ports is mainly focused on the performance measurement in accordance with the volume of traffic and productivity on a global scale [20]. In the strategic projections of transport corridors, the Danube-Sava Canal had its role in connecting the existing and planned corridors for transport of goods, and it would enable Croatia to connect with the Rhine-Danube corridor for the needs of combined or intermodal transport. Indirectly, direct connecting of the inland waterways (by the Danube-Sava Canal), would enable a better link of eastern Croatia with the Adriatic-Ionian Corridor, of particular importance for Croatia, which must necessarily protect its interests by conditioning the support to the new Alpine-Western Balkan corridor (Pan-European Corridor $X$ ), and, ultimately, its including in the TENtec (TransEuropean Transport Network). From the figure below (Fig. 9), it is evident that the canal enables further projection of the development of the Alpine-Western Balkan corridor. The visualization of temporal data is important for a variety 
of sciences and disciplines in understanding the space-time factors and the change. Analytically, showing a change in a setting is important for decision-making and forecasting future events. Different sets of software and techniques have been developed recently to apply spatiotemporal visualization and analysis [21]. Assigning of travelling, and the traffic distribution and visualization of the corridor for transport of goods in relation to the resources of the inland waterborne transport of the Republic of Croatia was done manually and verified by the analysis in QGIS.

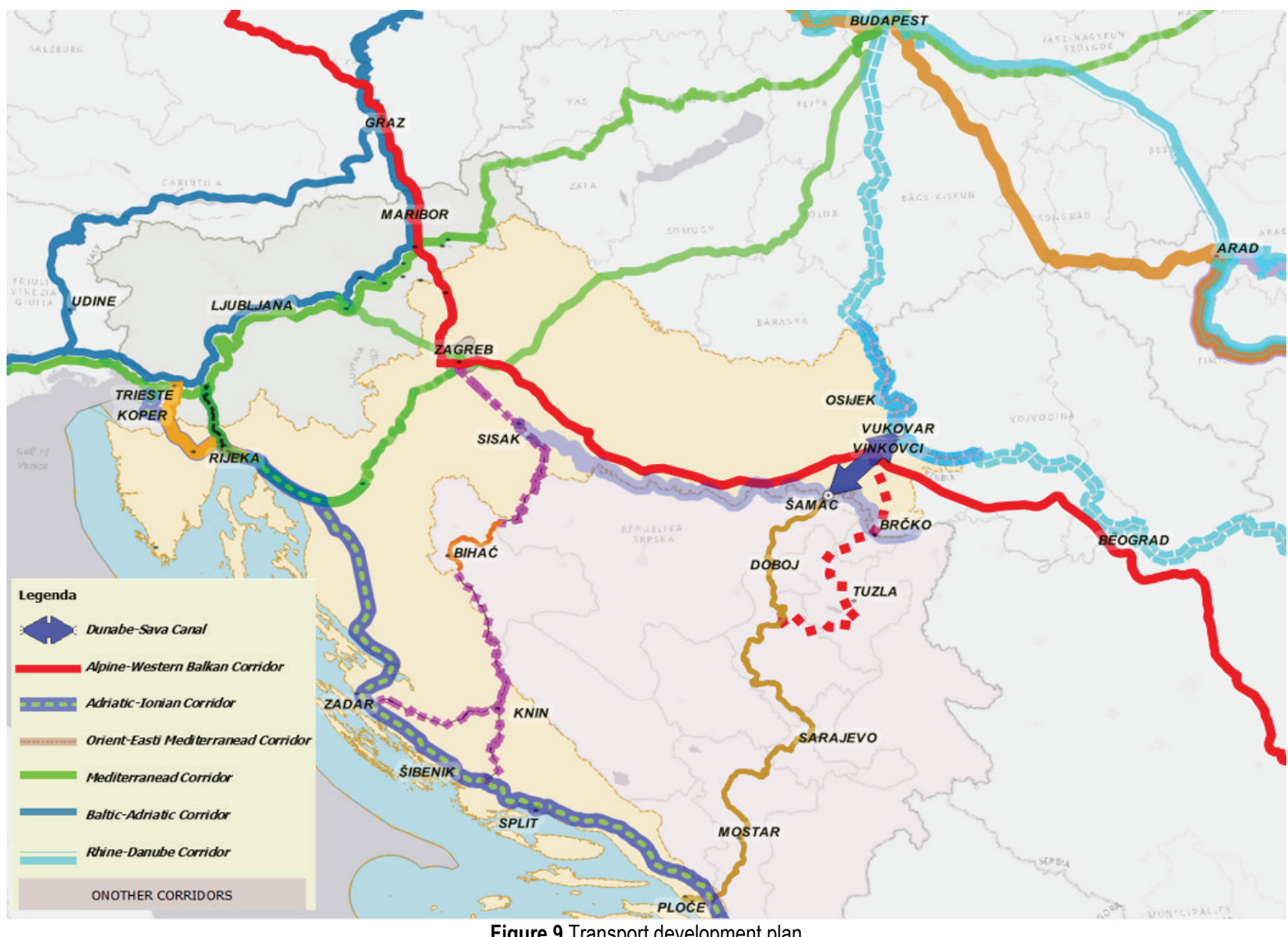

Figure 9 Transport development plan

\section{CONCLUSION}

The aim of studying the technology of goods transport is the optimisation and enhancement of the technological transport process flows. The overall river transport on the European transport corridors exceeds 650 million tons annually, whereas in Croatia this turnover is 577 thousand tons annually or as little as $0,58 \%$ out of the overall realised turnover in the Republic of Croatia. The reasons for such low transport efficiency lie in the following:

- insufficiently built up infrastructure,

- equipment of waterways and canals,

- obsolete technology of transport means,

- underdeveloped logistic network.

The development of port systems in the Republic of Croatia is important for the overall European transport system. Especially since there is a high relative density of the ports on the main corridor North Sea - Rhine - Danube - Black Sea. Therefore, it is also important for the Republic of Croatia to comply with the prescribed conditions that such ports must meet in the framework of the International Treaty on Major Waterways.

The role of inland waterways in the whole European transport system is evident through two approaches: the traditional one, which refers to ports as transhipment points where goods change the mode of transport from water to rail or road transport, and the approach in which ports are transformed into global or regional distribution or logistics centres. For this reason, planning of the construction and development of inland ports must necessarily take into account the possibilities of the complementary and ancillary functions that European ports on inland waterways should have.

Complementary functions include related services that create an added value in the transhipment and storage process and include various forms of processing of the transport substrate, such as, bulk cargo separation and sorting according to different quality of granules according to customer requirements, thermal, i.e. physicochemical processing, emptying of intermodal units, refilling, palletizing and redistribution, inspection, control, etc.

The project for the construction of the multifunctional Danube-Sava canal is also important because of the traffic integration of Croatian waterways, Croatian river ports and the creation of the conditions for intermodal interconnection of the Danube and the Adriatic in the framework of European transport corridors. It would allow parts of the road transport to be diverted to inland waterways, and with that, the cost of transporting largesized cargo would be reduced, as well as dangerous and highly flammable cargo.

Increasing the navigability class of navigable channels and the reorganization of cargo flows by road transport modes to inland waterways and the introduction of a 
modern transport technology, the construction and equipping of port capacities adequate for transshipment would encourage the development of integrated, intermodal and combined transport and reduce the energy consumption and environmental pollution. The required development and introduction of modern transport technology, construction and equipping of port capacities with adequate freight handling mechanization would stimulate also the development of integral, Intermodal and combined transport. In the integration with the European waterways the total annual transport capacity of the water transport in the Republic of Croatia would increase to 16,30 million tons annually, with the expected annual growth rate of $2,5 \%$ and the reach of the planned 20 million tons annually in the following ten-year period. The increase in the percentage share of the goods transport on inland water transport in the Republic of Croatia would increase from $0,2 \%$ to $10 \%$, which would become equal to the share percentage of the carried goods in water transport of the European Union.

The restructuring of traffic flows from road to more energy-efficient and environmentally friendly modes of transport in the Republic of Croatia, the construction of new and developing of the existing ports, the regulation and channelling of the Sava River and the construction of the channel "Danube-Sava" would increase the current percentage of navigability from $35,60 \%$ to $66,10 \%$, which would significantly reduce the energy consumption and pollution of the environment and transport costs. The technology of inland waterway is one of the largest contributions to the conservation of nature and environment for sustainable development, based on the low percentage of toxic emissions in the atmosphere and on the cost-effective use of non-renewable energy sources.

Therefore, in better positioning of Croatia in the TEN-T network, the solution for construction of the Danube-Sava canal should be taken over. Potential construction of the canal would open a prospect of connecting freight transport waterways through Croatia for combined and intermodal transport with the AlpineWestern Balkan corridor of utmost importance for Croatia, which would enable its potential including in the TEN-T network. Better links with the new Adriatic-Ionian Corridor and the trans-European Orient-East Mediterranean corridor would be realized. The report also takes in consideration the guidelines of the European Commission, which presents the transport and logistics development strategy in its documents, and recommends investments (a European idea contained in the White Book) in Europe's freight corridors for the purpose of achieving global advantages in solving the problems of the growing traffic.

Beside the arguments for the justification of the canal from the freight transport aspect, which are unquestionable because the corridor route of the canal unifies the existing corridors in a network, it would also have enormous potentials for acquisition of the international freight transport. Therefore, the Euro partnership can be anticipated in affirming and supporting the proposed construction of the canal ensuring a faster development of that part of Croatia, and strategic connecting in the European network of corridors for freight flows from and to Zagreb, and then also the port of Rijeka.

\section{REFERENCES}

[1] Golubenko, A., Gubacheva, L., \& Andreev, A. (2012). Forming the intermodal system of freight transportation on the east of Ukraine. Transport problems, 7(2), 27-35.

[2] Mindur, L. \& Hajdul, M. (2012). The concept of intermodal network development in Poland using multi-agent systems. Transport problems, 6(3), 5-16.

[3] White Paper. (2011). Roadmap to a Single European Transport Area - Towards a competitive and resource efficient transport system. European Commission, Brussels. Retrieved from http://eur-lex.europa.eu/legalcontent/EN/TXT/PDF/?uri=CELEX:52011DC0144\&from= EN.

[4] Nam, K. \& Win, E. (2014). Competitiveness between road and inland water transport: the case of Myanmar. Transport problems, 9(4), 49-61.

[5] (1996). European Agreement on Main Inland Waterways of International Importance $(A G N)$. United Nations, Economic Commission for Europe, Inland Transport Committee, Geneva, January 1996, 99. Retrieved from https://uia.org/s/or/en/1100039529

[6] (2008). Mid-term development plan of waterways and inland waterway ports of the Republic of Croatia (for the period from 2009 to 2016). Ministry of the Sea, Transport and Infrastructure, 85.

[7] Wiegleb, K. (1997). Wassertechnik, Band 4. Verlag für Bauwesen GmbH, Berlin, 739.

[8] Mortimer, P., Ribeiro, J., Kula, P., Balik, S., \& Mistodie, O. A. (2014). Design of integrated and co-ordinated multimodal transport systems - north see - Mediterranean corridor. Transport problems, 9(Special Edition), 71-88.

[9] (2009). Izvještaj EK o analitičkom pregledu i ocjeni usklađenosti nacionalnog zakonodavstva $\mathrm{s}$ pravnom stečevinom EU za Poglavlje 14. Prometna politika (Screening Report Croatia).

[10] International Sava River Basin Commission: DECIDION21/09. (June, 2009). International Sava River Basin Commission, Ref. No: WD-09-6/1-3, Zagreb.

[11] Hrvatska komora inženjera u graditeljstvu (Croatian Chamber of Civil Engineers). (March, 2010). Program razvojnih projekata u Hrvatskoj (Program of Development Projects in Croatia), 158 p.

[12] Državni zavod za statistiku (State Bureau of Statistics), transport i komunikacije (Transport and Communications). // 2012, $138 \mathrm{p}$.

[13] Prospects of Inland Navigation within the enlarged EuropeFinal Concise Report, 2004, 636. Retrieved from https://ec.europa.eu/transport/sites/transport/files/modes/inl and/studies/doc/2004_pine_report_report_concise.pdf

[14] Strateški okvir za razvoj RH 2006-2013. (2006). (Strategic frame for development of RH). Project of the Croatian Government from 2006, 79. Retrieved from https://razvoj.gov.hr/UserDocsImages/arhiva/Publikacije/St rateski_okvir_za_razvoj_2006_2013.pdf

[15] de Oliveira, M. M. F., Ebecken, N. F. F, de Oliveira, J. L. F., \& Aires, M. (2016). Numerical Modeling of Air Pollutants Emitted by Waterway Transportation. Journal of Geoscience and Environment Protection, 4(6), 123-136. https://doi.org/10.4236/gep.2016.46011

[16] Tzannatos, E., Tselentis, B., \& Corres, A. (2016). An inland waterway freight service in comparison to land-based alternatives in South-Eastern Europe: energy efficiency and air quality performance. Transport, 31(1), 119-126. https://doi.org/10.3846/16484142.2016.1129647

[17] Božičević, D. \& Kovačević, D. (2002). Suvremene transportne tehnologije (Modern Transport Technologies). Faculty of Traffic and Transport Sciences, Zagreb, 187.

[18] Jolić, N. (2004). Funkcionalni i simulacijski model inteligentnih transportnih sustava u Lukama (Functional and 
simulation model of intelligent transport systems in ports). PhD thesis, Faculty of Transport and Traffic Sciences, Zagreb.

[19] Pršić, M., Carević, D., \& Brčić, D. (2011). Determining inland waterway parameters with application to the Sava river. PROMET Traffic \& Transportation, 23(2), 147-154. https://doi.org/10.7307/ptt.v23i2.142

[20] Jurjević, M., Dundović, Č., \& Hess, S. (2016). A model for determining the competitiveness of the ports and traffic routes. Technical Gazette, 23(5), 1489-1496. https://doi.org/10.17559/TV-20140709100013

[21] Sharma, S., Tim, U. S., \& Gadia, S. (2018). Visual subsetting, conversion and complex query exploitation in large spatio-temporal databases. Computers \& Electrical Engineering, 67, 309-319. https://doi.org/10.1016/j.compeleceng.2017.06.015

\section{Contact information:}

Grgo LUBURIĆ, PhD, Full. Prof.

University of Zagreb,

Faculty of Transport and Traffic Sciences (FTTS),

Vukelićeva 4, HR-10000 Zagreb, Croatia

E-mail: gluburic@fpz.hr

Damir BUDIMIR, PhD, Eng.

(Corresponding author)

University of Zagreb,

Faculty of Transport and Traffic Sciences (FTTS)

Vukelićeva 4, HR-10000 Zagreb, Croatia

E-mail: damir.budimir@fpz.hr

\section{Ivan BORTAS, Eng.}

Arhitektika projekt d.0.0.

Ante Starčevića 23, HR-10000 Zagreb, Croatia

E-mail: arhitektikaprojekt@inet.hr 